\title{
Analisis dan Studi Eksperimen Perbandingan Transmisi Manual dengan Transmisi CVT pada Mobil Honda Jazz 2018, Berdasarkan Karakteristik Traksi dan Efisiensi Transmisi
}

\author{
Rafi Rasyad dan I Nyoman Sutantra \\ Departemen Teknik Mesin, Fakultas Teknologi Industri, \\ Institut Teknologi Sepuluh Nopember (ITS) \\ e-mail: tantra@me.its.ac.id
}

\begin{abstract}
Abstrak-Teknologi otomotif mengalami perkembangan pesat beberapa tahun terakhir, begitu pula dari sektor mobil. Variabel yang mengalami perubahan adalah tipe transmisi yang digunakan. Melihat banyak nya penjualan mobil bertransmisi otomatis, seharusnya pihak produsen mengimbanginya dengan upaya memberikan informasi detail mengenai perbedaan transmisi pada mobil kepada konsumen dalam upaya mencerdaskan konsumen. Perbedaan sistem transmisi juga menghasilkan performa yang berbeda juga. Sehingga perbedaan itulah yang mendasari penulis untuk melakukan analisis dan studi eksperimen perbandingan transmisi manual dengan transmisi cvt pada mobil Honda Jazz 2018, berdasarkan karakteristik traksi dan efisiensi transmisi. Dalam penelitian ini, penulis akan melakukan tiga tahapan penelitian. Tahapan pertama adalah melakukan pengujian dynotest pada kedua tipe transmisi mobil untuk mengetahui daya aktual serta efisiensi transmisi. Tahap kedua, dilakukan analisa perhitungan sehingga di dapatkan grafik karakteristik mobil. Selanjutnya tahap ketiga dilakukan perbandingan terhadap grafik karakteristik tiap transmisi mobil berdasarkan efisiensi transmisi yang akan diolah dalam bentuk perbandingan grafik. Dari penelitian ini diperoleh grafik karakteristik traksi mobil. Pengujian dynotest menunjukan efisiensi transmisi total dari mobil Jazz transmisi cvt sebesar $\mathbf{6 0 , 2 \%}$ dan manual sebesar $\mathbf{7 1 , 2 \%}$. Setelah dilakukan analisa, terhadap karakteristik traksi pada tiap tipe transmisi didapatkan bahwa transmisi cvt memiliki nilai traksi maksimum $3,708 \mathrm{kN}$, mampu melewati tanjakan maksimum sebesar $19,862^{\circ}$, memiliki kecepatan maksimum $188 \mathrm{~km} / \mathrm{jam}$ dan percepatan sebesar $3,332 \mathrm{~m} / \mathrm{s} 2$ sedangkan transmisi manual memiliki nilai traksi maksimum $5,33 \mathrm{kN}$, mampu melewati tanjakan maksimum sebesar $32,248^{\circ}$, memiliki kecepatan maksimum $182 \mathrm{~km} / \mathrm{jam}$ dan percepatan sebesar $5,232 \mathrm{~m} / \mathrm{s} 2$.
\end{abstract}

Kata Kunci-Transmisi, Manual, Cvt, Dynotest, Efisiensi, Karakteristik Traksi.

\section{PENDAHULUAN}

$\mathrm{T}$ EKNOLOGI otomotif mengalami perkembangan pesat beberapa tahun terakhir, begitu pula dari sektor mobil, yang juga diiringi dengan tingginya penjualan kendaraan di pasar otomotif global tidak terkecuali Indonesia. Berdasarkan data Gabungan Industri Kendaraan Bermotor Indonesia (Gaikindo) menunjukkan penjualan mobil pada kuartal bulan Juli 2018 tercatat sebanyak 107.431 unit, dan membuktikan kebutuhan akan kendaraan di Indonesia sangat tinggi.

Variabel yang mengalami perubahan adalah tipe transmisi. menurut data dari Indian Microfinance Sector (ICRA) perbandingan penjualan mobil dunia dari segi transmisi manual dan transmisi otomatis mengalami perkembangan dimana dengan pertambahan penjualan mobil volume kendaraan dijalan akan meningkat yang menyebabkan konsumen beralih ke transmisi otomatis, bahkan di USA pemakaian kendaraan bertransmisi otomatis sudah melebihi angka $95 \%$ di tahun 2017 [1]

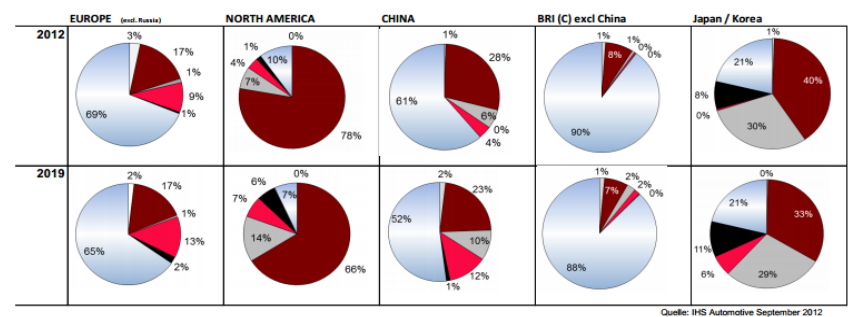

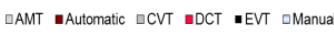

Gambar 1. Prediksi penggunaan tipe transmisi [2].

Melihat tingginya tingkat produksi dan penjualan mobil di Indonesia dan melihat arah perkembangan penjualan dari tipe transmisi, seharusnya pihak produsen mengimbanginya dengan upaya memberikan informasi detail mengenai mobil kepada konsumen seperti yang telah dilakukan di beberapa negara maju dalam upaya mencerdaskan konsumen.

Dari penelitian yang dilakukan oleh A. Irimescu, L. Mihon dan G. Padure dengan topik Automotive Transmission Efficiency Measurement Using a Chassis Dynamometer dimana dihasikan metode untuk mengukur efisiensi transmisi menggunakan chassis dynamometer, dengan perbandingan antara mobil Front Wheel Drive dan Rear Wheel Drive menjadi dasar untuk pengujian maupun analisa dari penelitian.

Perbedaan sistem transmisi juga menghasilkan performa yang berbeda juga. Sehingga perbedaan itulah yang mendasari penulis untuk melakukan analisis dan studi eksperimen perbandingan transmisi manual dengan transmisi cvt pada mobil Honda Jazz 2018, berdasarkan karakteristik traksi dan efisiensi transmisi

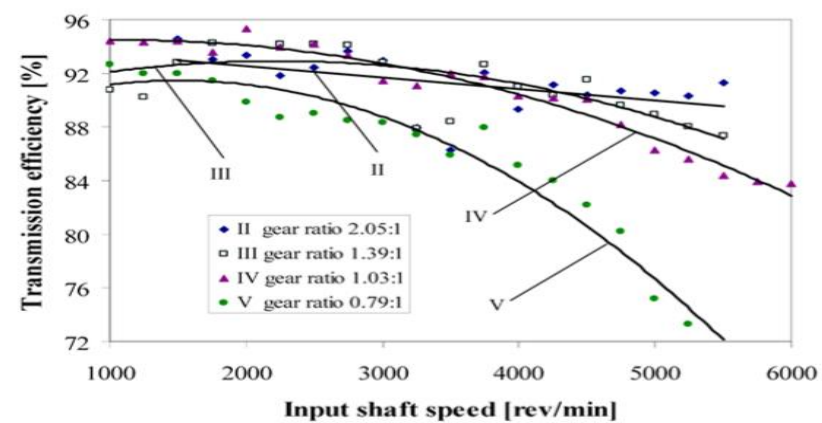

Gambar 2. Efisiensi transmisi FWD [3]. 


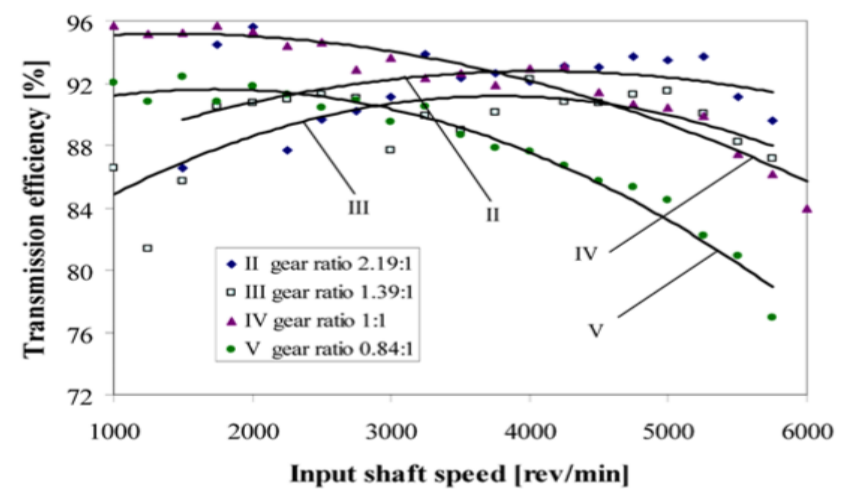

Gambar 3. Efisiensi transmisi RWD [3].

\section{METODE PENELITIAN}

Adapun metodologi penelitian yang dilakukan dapat diilustrasikan dalam sebuah flowchart seperti Gambar 4 berikut,

\section{STUDI LITERATUR}

Penelitian ini diawali dengan melakukan studi literatur. Pada bagian ini dilakukan pengumpulan literatur berupa buku, jurnal, serta katalog yang dapat mendukung penelitian tugas akhir ini. Referensi tersebut erat kaitanya dengan penelitian mengenai analisa karakteristik traksi, informasi mengenai spesifikasi kendaraan, serta penelitian mengenai perbandingan dari sistem transmisi maupun sistem transmisi tertentu.

\section{MENGHITUNG GAYA HAMBAT KENDARAAN}

Gaya-gaya yang bekerja pada sebuah kendaraan yang sedang melaju pada sebuah permukaan dengan sudut tanjak tertentu dapat dijabarkan dalam Gambar 5.

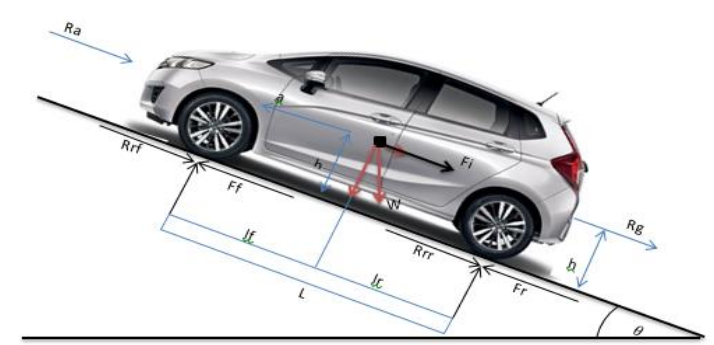

Gambar 5. Dinamika kendaraan mobil.

Ft adalah gaya dorong kendaraan oleh mesin pada roda penggerak. Pada Gambar 5, Ft (gaya dorong) dibagi menjadi dua yaitu $F f$ (gaya dorong pada roda depan) dan $F r$ (gaya dorong pada roda belakang). Gaya dorong pada kendaraan yang sedang berjalan,dihambat oleh tiga macam gaya hambat yaitu, drag force, rolling resistance serta gaya hambat kendaraan akibat sudut tanjak [4] .

\section{1) Gaya Hambat Angin}

Gaya hambat karena udara pada mobil disebut dengan drag force. Pada dasarnya, terdapat beberapa jenis gaya hambat angin pada kendaraan yaitu hambatan bentuk, hambatan pusaran, hambatan tonjolan, serta hambatan aliran dalam. Namun gaya hambat yang paling besar adalah akibat gaya hambat bentuk dan pusaran. Dengan demikian, besarnya gaya hambat angin dapat dihitung dengan persamaan berikut [5],

dimana,

$$
R a=1 / 2 \times \rho \times C d \times A f_{X} V a
$$

$R a$ = hambatan aerodinamika $(\mathrm{N})$

$\rho \quad=$ massa jenis udara $\left(\mathrm{kg} / \mathrm{m}^{3}\right)$

$C d=$ koefisien drag

Af $=$ luas frontal kendaraan $\left(\mathrm{m}^{2}\right)$

$V a=$ kecepatan relatif angin terhadap kendaraan $(\mathrm{m} / \mathrm{s})$

Besarnya $C d$ Honda Jazz 0.33, sedangkan luasan frontal area sebesar $1,79 \mathrm{~m}^{2}$.

\section{2) Gaya Hambat Rolling}

Gaya yang kedua adalah rolling resistant. Yaitu gaya hambat akibat gesekan ban dengan jalan. Untuk mencari besarnya gaya hambat ini, pertama kita harus menentukan besarnya koefisien hambatan rolling (fr) terlebih dahulu. Besarnya fr dapat dicari menggunakan persamaan berikut [5],

$$
F r=f o+f s(V k .100)^{2,5}
$$

dimana,

$f r \quad=$ koefisien hambat rolling

fo dan $f s=$ koefisien yang nilainya tergantung pada tekanan ban, didapat dari grafik Gambar 6

$V k=$ kecepatan kendaraan $(\mathrm{km} / \mathrm{h})$ 


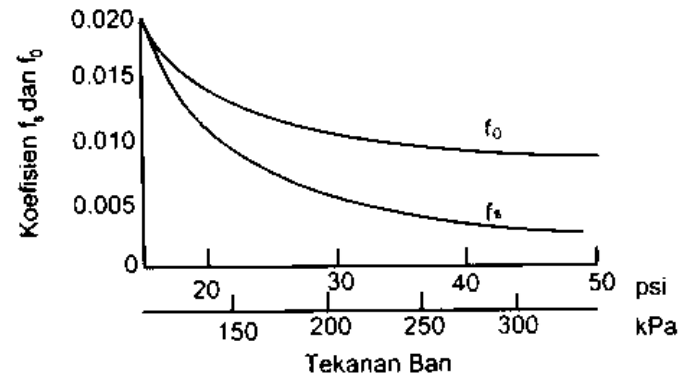

Gambar 6. Grafik pengaruh tekanan ban pada fo dan fs [6].

\section{3) Gaya Hambat Tanjakan}

Gaya hambat yang ketiga adalah gaya hambat tanjakan, yaitu gaya hambat yang diakibatkan adanya sudut tanjak yang dilewati oleh kendaraan sehingga beban kendaraan akan bertambah akibat gaya gravitasi yang muncul. Besarnya gaya hambat akibat sudut tanjak dapat dihitung dengan rumus berikut,

$$
\begin{aligned}
& R g=W \sin \theta=\text { hambatan tanjakan }(N) \\
& \text { dimana, } \\
& \begin{array}{l}
W \quad=\text { berat mobil } \\
\theta \quad=\text { sudut tanjak }
\end{array}
\end{aligned}
$$

Ketika kendaraan dalam posisi menanjak, digunakan satuan gradeability sebagai acuan. Jika kendaraan didesain dengan gradeability $30 \%$ misalnya, maka kemampuan kendaraan tersebut harus mampu menanjak dengan gradeability sebesar $30 \%$. Jika kendaraan tersebut belum mampu menempuh tanjakan tersebut, maka kendaraan tersebut dikatakan tidak memenuhi kriteria gradeability yang disyaratkan [3].

Perhitungan gradient tanjakan $(\mathrm{G})$ dapat dilakukan dengan rumus berikut,

$$
\mathrm{G}=\tan \theta \times 100 \%=\frac{(\text { vertical projection })}{(\text { horizontal projection })} \times 100 \%
$$

Dengan demikian, setelah meninjau tiga buah gaya hambat yang bekerja pada kendaraan sesuai penjelasan sebelumnya, maka gaya hambat total pada kendaraan dapat dirumuskan sesuai persamaan 5 ,

$$
F r=R a+R r+R g
$$

\section{MENGHITUNG GAYA DORONG KENDARAAN}

Gaya Dorong adalah gaya yang bekerja berlawanan dengan arah gerak gaya hambat kendaraan. Gaya dorong ini dihasilkan dari daya yang dihasilkan oleh mesin kendaraan (engine) yang kemudian disalurkan melalui sistem transmisi sehingga akhirnya dapat menggerakan roda. Untuk menghitung besarnya gaya dorong yang mampu dihasilkan kendaraan, dapat digunakan persamaan 6 dan 7 [5].

$$
\begin{aligned}
& F t(\text { manual })=\frac{i t \cdot i g \cdot M e}{r} \eta t \\
& F t(c v t)=\frac{i v t \cdot \mathrm{Ctr} \cdot M e}{r} \eta t
\end{aligned}
$$

dimana,

$M e=$ torsi keluaran dari mesin (N.m)

$r \quad=$ jari-jari roda $(\mathrm{m})$

$\eta t=$ efisiensi transmisi

it $=$ perbandingan gigi transmisi

$i v t=$ perbandingan rasio pulley

ig = perbandingan transmisi pada gardan

$C t r=$ perbandingan rasio torsi konventer

\section{DYNOTEST}

Pengujian ini dilakukan dengan 2 mobil Honda Jazz 2018 dengan transmisi manual dan cvt, dengan memperhatikan pengkondisian yang sama dan memakai sistem chassis dyno. Dyno yang digunakan menggunakan jenis on-wheel dynamometer, dengan skema pengujian berdasarkan Gambar 7.

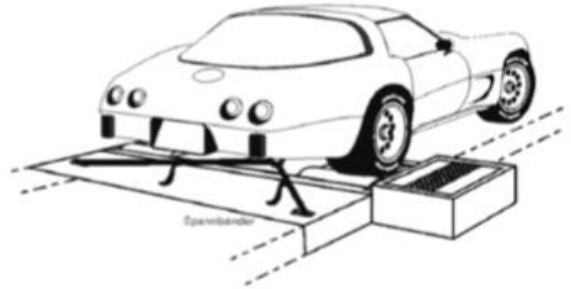

Gambar 7. Skema pengujian dynotest [3].

Dimana nilai torsi dari pengujian akan dibandingkan dengan nilai torsi dari mesin dengan rumus berikut,

$$
\eta_{t}=\frac{\text { torsi maksimum pengujian }}{\text { torsi maksimum engine }}
$$

\section{KARAKTERISTIK TRAKSI}

Untuk memudahkan kita mengetahui karakteristik transmisi kendaraan, maka dibuat grafik untuk gaya dorong kecepatan. Pada grafik tersebut ditunjukkan hambatan rolling $(R r)$, aerodinamik $(R a)$, serta tanjak yang terjadi pada kendaraan, serta gaya dorong total, gaya dorong bersih, dan gaya dorong maksimum yang dapat terjadi pada bidang ${ }^{[4]}$.

Gaya dorong bersih $(F n)$ yang dimaksudkan adalah gaya dorong total dikurangi hambatan rolling dan hambatan aerodinamika, dirumuskan sebagai berikut:

$$
F n=F-R r-R a
$$

Dikarenakan mobil Jazz yang dijadikan objek penelitian memiliki 2 jenis transmisi, dimana digunakan torsi converter untuk menyalurkan daya output engine menuju transmisi pada cvt, maka grafik traksi nya akan terlihat lebih landai dibandingkan transmisi manual untuk masing-masing tingkat kecepatan.

\section{HASIL DAN ANALISIS}

Berdasarkan data teknis dan spesifikasi kendaraan Honda Jazz 2018, dibuat karakteristik traksi dan kinerja transmisinya dengan memperhatikan dalam beberapa batasan:

1. Kendaraan yang dianalisa adalah Honda Jazz 2018 MT dan Honda Jazz 2018 CVT.

2. Analisa yang dilakukan dalam kondisi mobil terisi 1 penumpang dengan berat orang $60 \mathrm{~kg}$.

3. Tekanan ban 30 psi.

4. Kinerja engine tidak dipengaruhi lingkungan sekitar.

5. Jalan yang dilalui rata (tidak bergelombang).

6. Tidak ada slip pada ban yang terjadi.

7. Beban angin yang terjadi pada kendaraan yaitu gaya hambat (drag).

\section{A. Perhitungan Efisiensi Transmisi Berdasarkan Uji Dynotest}

Besarnya efisiensi transmisi $(\eta \mathrm{t})$ diperoleh dengan membandingkan nilai torque loss maksimum dengan torsi maksimum pada engine pada tiap-tiap transmisi. Seperti pada Gambar 6. 


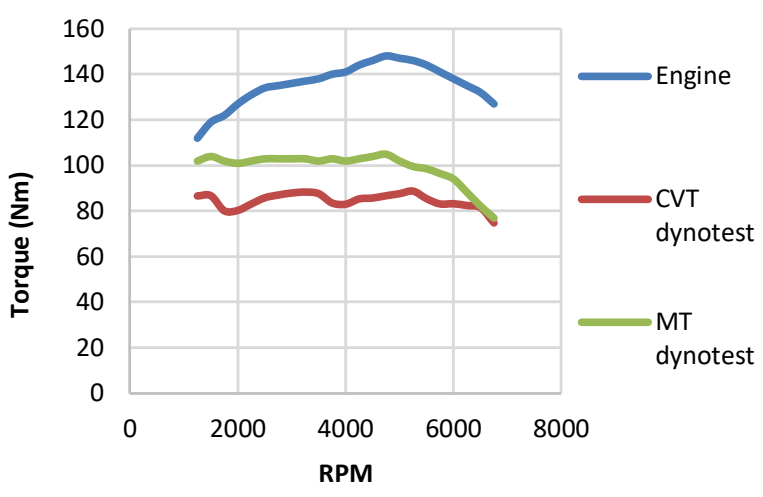

Gambar 6. Grafik perbandingan grafik torsi vs rpm.

Dan dengan menggunakan rumus 8 , maka didapatkan hasil dari pengujian dynotest yang telah dilakukan dengan hasil transmisi manual menghasilkan torsi maksimum sebesar 104 $\mathrm{N}-\mathrm{m}$ dengan efisiensi transmisi sebesar $71,2 \%$ sedangkan transmisi cvt sebesar $88 \mathrm{~N}-\mathrm{m}$ dengan efisiensi transmisi sebesar $60,6 \%$.

\section{B. Perhitungan Gaya Hambat Kendaraan}

Dengan menggunakan rumus 5, maka di dapatkan grafik gaya hambat total sebagai berikut

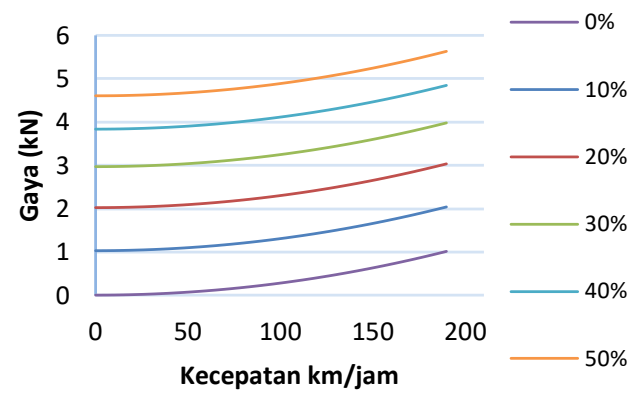

Gambar 8. Grafik gaya hambatan total Jazz MT.

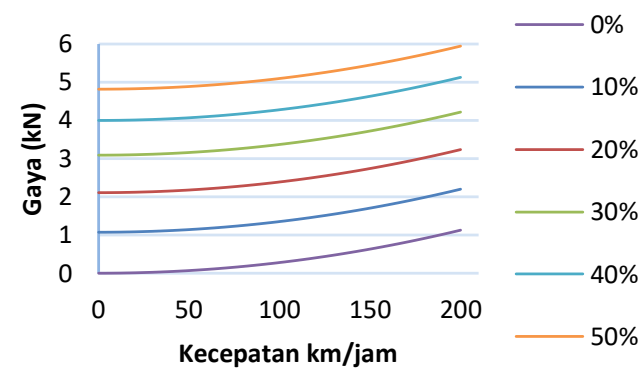

Gambar 9. Grafik gaya hambatan total Jazz CVT.

\section{Perhitungan Gaya Dorong Kendaraan}

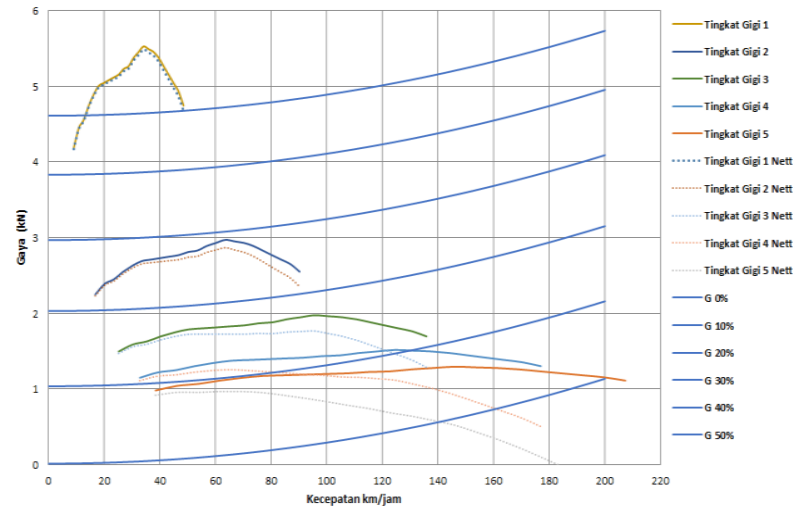

Gambar 10. Grafik karakteristik traksi Jazz MT.
Nilai gaya dorong diperoleh menggunakan rumus 6 dan 7 . Dengan menggabungkan hasil dari efisiensi transmisi total $(\eta t)$, gaya hambatan total kendaraan, dan berdasarkan spesifikasi kendaraan dari tiap variabel transmisi. Didapatkan grafik karakteristik traksi kendaraan yang disajikan pada Gambar 10.
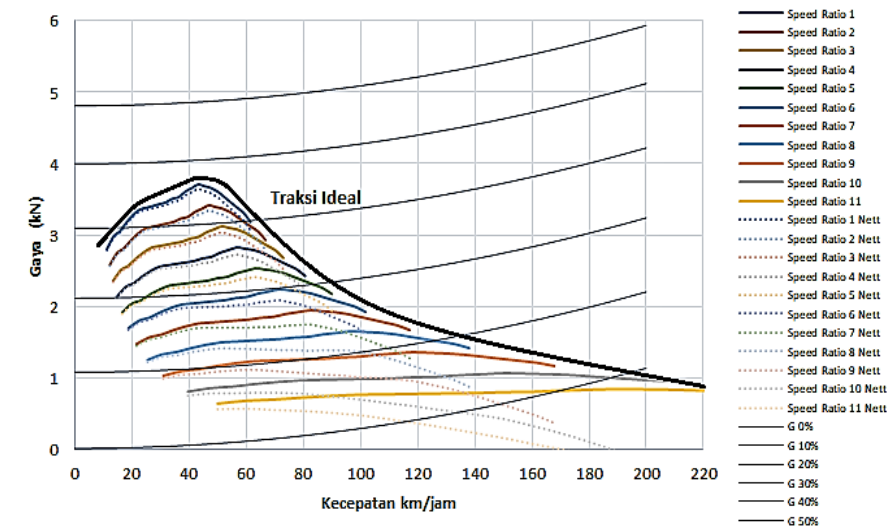

Gambar 11. Grafik karakteristik traksi Jazz CVT.

Dapat dilihat dari grafik karakteristik traksi dimana tidak terdapat losses traksi pada transmisi cvt dibandingkan dengan transmisi manual yang memiliki losses traksi di tiap tingkat gigi dengan losses traksi terbesar pada tingkat gigi 1 ke tingkat gigi 2 dengan nilai sebesar 2,223 Kn dimana permasalahan losses traksi dapat diperbaiki dengan membuat rasio transmisi baru menggunakan teori progresi geometri dan merupakan salah satu tujuan dari sistem transmisi cvt untuk menghilangkan losses traksi yang terjadi pada tiap perpindahan gigi. Dari grafik karakteristik traksi diatas kita dapat membuat beberapa parameter perbandingan yang dapat digunakan sebagai acuan dari tiap variabel sistem transmisi dari tanjakan maksimum maupun kecepatan maksimum yang dapat ditempuh.

\section{Perhitungan Percepatan Kendaraan}

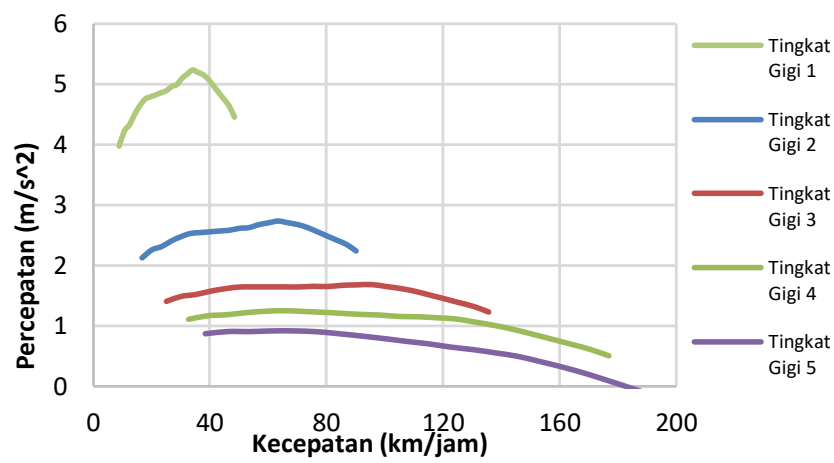

Gambar 12. Grafik percepatan Jazz MT

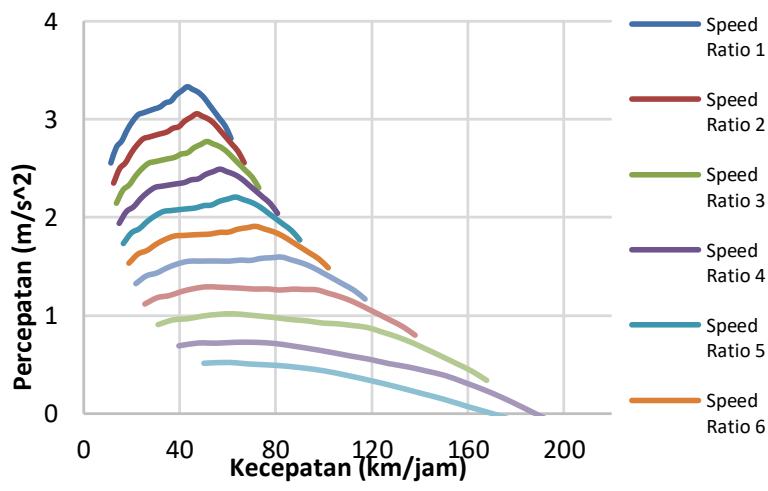

Gambar 13. Grafik percepatan Jazz CVT. 
Nilai percepatan dapat kita dapatkan dari grafik karakteristik traksi untuk mengetahui kemampuan akselerasi dari tiap variabel transmisi manual maupun cvt dengan nilai gaya dorong yang didapatkan dibagi dengan massa kendaraan total. Didapatkan grafik percepatan yang disajikan pada Gambar 12 dan 13.

\section{E. Perbandingan Tanjakan Maksimum}

Setelah dilakukan analisa dan perhitungan berdasarkan efisiensi transmisi untuk mencari karakteristik traksi dari transmisi manual dan transmisi cvt, didapatkan grafik perbandingan tanjakan maksimum sebagai berikut,

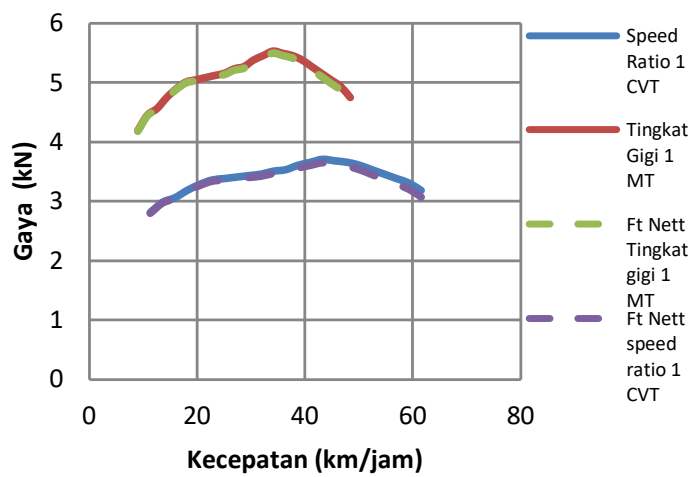

Gambar 14. Grafik perbandingan tanjakan maksimum.

Nilai gaya dorong (Ft) terbesar dari masing-masing transmisi, dimana pada transmisi manual didapatkan pada tingkat gigi 1 dengan nilai Ft sebesar 5530,383 N dan pada transmisi CVT didapatkan pada speed ratio 1 dengan nilai $\mathrm{Ft}$ sebesar 3708,023 N. Nilai tanjakan maksimum dapat dihitung dengan rumus 2.24 sebagai berikut,

$$
\theta_{\text {max }}=\arcsin \left(\frac{F_{t}-R_{r}-R_{a}}{W}\right)
$$

Dimana Ft-Rr-Ra merupakan gaya dorong bersih maksimum yang dapat dicapai dan $\mathrm{W}$ adalah berat dari tiap mobil. Diketahui nilai gaya dorong bersih dari transmisi manual sebesar $5489 \mathrm{~N}$ dengan berat $1049 \mathrm{~kg}$ dan nilai gaya dorong bersih transmisi CVT sebesar $3645 \mathrm{~N}$ dengan berat $1094 \mathrm{~kg}$.

$$
\begin{aligned}
& \theta_{M T}=\arcsin \left(\frac{5489 N}{10287 N}\right) \\
& \theta_{M T}=32,248^{\circ} \\
& \theta_{C V T}=\arcsin \left(\frac{3645 N}{10728 N}\right) \\
& \theta_{C V T}=19,862^{\circ}
\end{aligned}
$$

Dari nilai tanjakan maksimum diatas dan dapat dilihat bahwa transmisi yang digunakan pada Jazz MT dapat melewati tanjakan maksimum sebesar $32,248^{\circ}$ jika dibandingkan dengan Jazz CVT yang hanya mampu melewati tanjakan maksimum sebesar $19,862^{\circ}$.

\section{F. Perbandingan Kecepatan Maksimum}

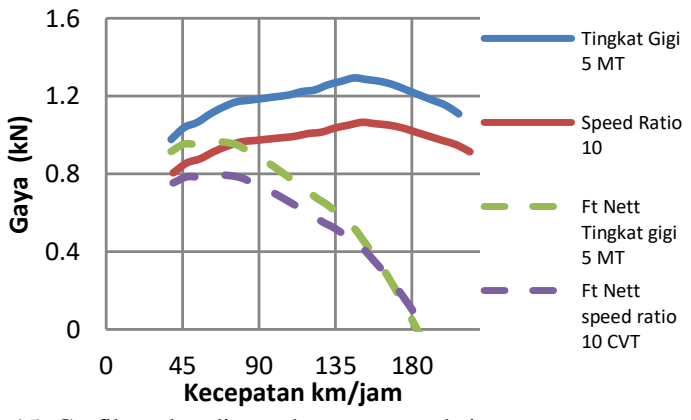

Gambar 15. Grafik perbandingan kecepatan maksimum.
Tabel 1

Perbandingan transmisi manual dan cvt

Perbandingan Transmisi

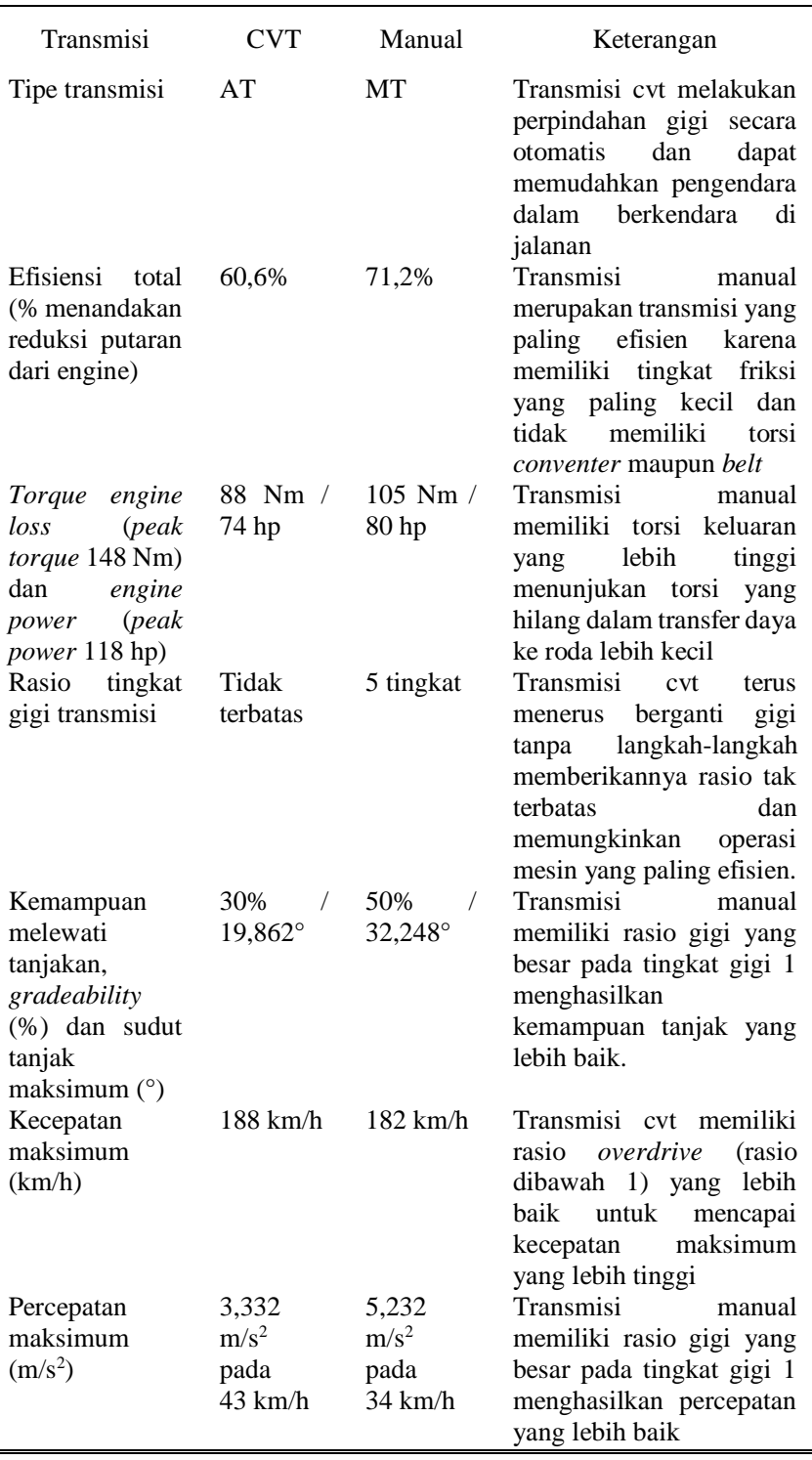

Setelah dilakukan analisa dan perhitungan berdasarkan efisiensi transmisi untuk mencari karakteristik traksi dari transmisi manual dan transmisi cvt, didapatkan grafik perbandingan kecepatan maksimum yang disajikan pada Gambar 15.

Dari Gambar 15 dapat dilihat perbandingan grafik gaya dorong dari speed ratio $10 \mathrm{CVT}$ dengan grafik gaya dorong dari tingkat gigi 5 MT. Dari grafik yang didaptkan melalui pengujian dan analisa didapatkan nilai kecepatan (V) terbesar dari masing-masing transmisi, dimana pada transmisi manual didapatkan pada tingkat gigi 5 dengan nilai V sebesar 182 $\mathrm{km} / \mathrm{jam}$ dan pada transmisi CVT didapatkan pada speed ratio 10 dengan nilai $\mathrm{V}$ sebesar $188 \mathrm{~km} / \mathrm{jam}$.

\section{G. Perbandingan Percepatan Maksimum}

Setelah dilakukan analisa dan perhitungan berdasarkan efisiensi transmisi untuk mencari karakteristik traksi dari transmisi manual dan transmisi cvt, didapatkan grafik perbandingan percepatan maksimum yang disajikan pada Gambar 16.

Dari Gambar 16 dapat dilihat grafik percepatan sebagai fungsi kecepatan pada kendaraan Jazz MT dan Jazz CVT. Terlihat bahwa antara grafik gaya dorong dengan grafik 
percepatan kendaraan memiliki kesamaan trendline, sebab besarnya percepatan kendaraan merupakan gaya dorong bersih kendaraan yang dibagi dengan masa total kendaraan yang nilainya konstan. Dari kedua grafik diatas dapat dilihat adanya perbedaan trendline. Pada Jazz MT percepatan maksimum sebesar $5,232 \mathrm{~m} / \mathrm{s}^{2}$ dan berada pada kecepatan 34 $\mathrm{km} / \mathrm{jam}$ sementara pada Jazz CVT percepatan maksimum sebesar 3,332 $\mathrm{m} / \mathrm{s}^{2}$ terjadi pada kecepatan $43 \mathrm{~km} / \mathrm{jam}$.

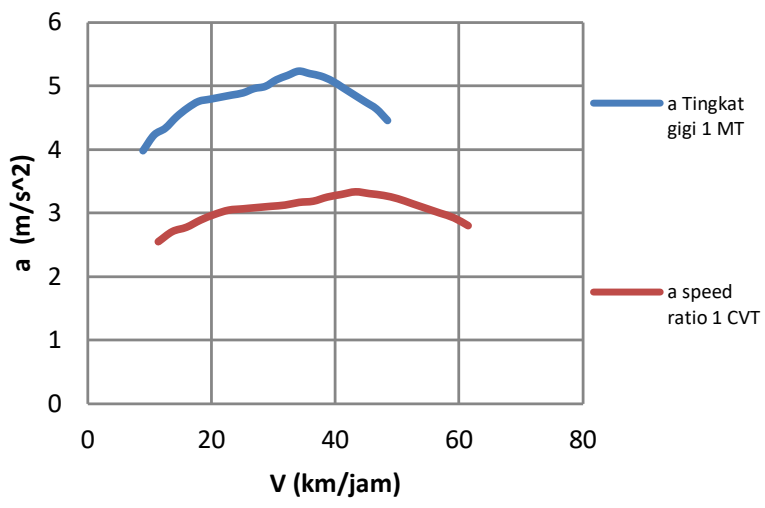

Gambar 16. Grafik perbandingan percepatan maksimum.

\section{H. Perbandingan Transmisi Manual dan CVT}

Setelah melakukan pengujian maupun analisa perbandingan transmisi cvt dan manual didapatkan data perbandingan yang ditampilkan pada Tabel 1 .

\section{KESIMPULAN}

Berdasarkan data dan analisa dari pengujian maupun perhitungan dan analisa didapatkan kesimpulan dari perbandingan tipe transmisi. Hasil pengujian dynotest didapatkan grafik engine torque loss dimana efisiensi transmisi total dari mobil Jazz tansmisi manual sebesar 71,2\% mampu melewati tanjakan maksimum dengan gradeability lebih dari $50 \%$ sebesar $32,248^{\circ}$, memiliki kecepatan maksimum pada tingkat gigi 5 sebesar $182 \mathrm{~km} / \mathrm{jam}$, dan percepatan maksimum sebesar $5,232 \mathrm{~m} / \mathrm{s}^{2}$ pada $34 \mathrm{~km} / \mathrm{jam}$ sedangkan dari mobil Jazz transmisi cvt sebesar 60,6\%, mampu melewati tanjakan maksimum dengan gradeability lebih dari $30 \%$ sebesar $19,862^{\circ}$, memiliki kecepatan maksimum pada speed ratio 10 sebesar $188 \mathrm{~km} / \mathrm{jam}$, dan percepatan maksimum sebesar $3,332 \mathrm{~m} / \mathrm{s}^{2}$ pada $43 \mathrm{~km} / \mathrm{jam}$ Didapatkan data dari pengujian maupun analisa, dari segi efisiensi total, torque engine loss dan engine power, kemampuan melewati tanjakan dan sudut tanjak maksimum, dan percepatan maksimum transmisi manual lebih baik dibandingkan dengan transmisi cvt. Akan tetapi data dari segi tipe transmisi, rasio tingkat gigi transmisi, dan kecepatan maksimum menunjukan transmisi cvt lebih baik dibandingkan dengan transmisi manual.

\section{DAFTAR PUSTAKA}

ICRA Research, "Comparison of Automobiles Sales Based on Transmissin," 2016.

[2] P. 2 B. on E. and E. S. D. on E. and P. S. C. Committee on the Assessment of Technologies for Improving Fuel Economy of Light-Duty Vehicles, Effectiveness And Deployment Of Fuel Economy Technologies For Light-Duty Vehicles. Washington D.C.: The National Academic Press, 2004.

[3] A. Irimescu, L. Mihon, and G. Pãdure, "Automotive transmission efficiency measurement using a chassis dynamometer," Int. J. Automot. Technol., vol. 12, no. 4, pp. 555-559, Aug. 2011.

[4] N. Wardhana, "Analisis Karakteristik Traksi Serta Redesign Rasio Transmisi Toyota Fortuner 4.0 V6 SR (AT 4 x 4)," Surabaya, 2016 B. S.I. Nyoman., Sampurno, Teknologi Otomotif Edisi Kedua. Guna Widya, 2010.

[6] J. J. Taborek, Mechanics of Vehicles. Ohio: Penton Publishing Co, 1957. 